\title{
EM TEMPOS DE GLOBALIZAÇÃO, QUE DE NOVO SE ENUNCIA?
}

\author{
Sílvia Helena Barbi Cardoso
}

RESUMO: This paper shows how the concern with Discourse Analysis can be combined with broader problems of social nature. The aim is to question whether there is a new significant discourse besides the one belonging to the reigning neoliberal ideology. Our hypothesis is that total hegemony does not exist - nowadays it is possible to find significant heterogeneity among discourses which apparently are not so important and do not apparently constitute themselves as a political challenge to globalization or neoliberal system, such us the one belonging to the revolutionary movement of peasants in Brazil, or even the one belonging to the International Social Forum. On the track of these new discourses, two documents of linguistic politics are brought to discussion: Universal Declaration of Linguistic Rights and a Brazilian project of law.

PALAVRAS-CHAVE: enunciação, discurso, memória discursiva, sujeito, identidade, globalização, neoliberalismo

O objeto de uma análise do discurso, em uma primeira abordagem, parece ser o de descrever uma seqüencia real única e não repetível. (J. M. Marandin)

Sílvia Helena Barbi Cardoso é professora aposentada pela Universidade Federal de Uberlândia (UFU); ex-professora adjunto da Universidade Federal de Minas Gerais; professora coordenadora, responsável, junto ao MEC, pelo projeto do curso de Letras da Faculdade de Americana (FAM); professora da Universidade São Marcos. 


\section{INTRODUÇAOO}

Nesses últimos onze anos, subseqüentes à implosão da União Soviética, a tão propalada bipolaridade da sociedade mundial, capitalismo $\mathrm{X}$ comunismo, viu-se ameaçada. O capitalismo, que antes era impedido de expandir-se livremente pelo planeta, conquistou a hegemonia política, econômica e dos meios de comunicação, de uma forma sem precedentes. Conhecido como "globalização", esse processo de expansão, iniciado com a desagregação do bloco soviético e a transformação do mundo socialista em vasta fronteira de expansão do capitalismo, levou os detentores do capital financeiro a proclamar que o neoliberalismo realmente funciona como a única forma eficaz para todas as sociedades do planeta.

Perguntamo-nos, então, que momento é este em que socialistas antigos são chamados para gerir os negócios da burguesia e do neoliberalismo. Um momento de estagnação política, em que a história finalmente encontrou a fórmula para a solução dos problemas da humanidade? Ou um momento de transição em que formulações novas estão sendo geridas enquanto respostas ao discurso da "aldeia global"?

O título deste trabalho é propositalmente ambíguo, pois "QUE DE NOVO SE ENUNCIA?" tanto pode significar "enuncia-se novamente o mesmo?", ou "enuncia-se uma coisa nova, diferente?". Tendo consciência de que um discurso novo sempre depende de pré-construídos, constituindo-se enquanto efeito de redes sócio-históricas e um trabalho de deslocamento nessas redes, acreditamos que, se ficarmos atentos aos lugares enunciativos recuperáveis ao longo de determinados textos de manifesto à hegemonia neoliberal, talvez seja possível seguir as trilhas de um novo discurso (ou até mesmo mais de um).

A nossa hipótese é que, se quisermos compreender a heterogeneidade discursiva no atual momento, devemos investigar os discursos de efeito social colateral que o próprio sistema neoliberal engendra. O objetivo deste trabalho é rastrear algumas manifestações verbais desses novos discursos.

\section{PERSPECTIVA TEÓRICA}

Apoiamo-nos teoricamente nos desenvolvimentos da análise do discurso francesa, mais especificamente nos trabalhos que, a partir de 1980, centralizam o heterogêneo e o acontecimento discursivo, ao mesmo tempo em que "permitem circunscrever o papel da categoria da enunciação na história da análise do discurso" (GUILHAUMOU; MALDIDIER, 1989, 
p. 61).

Os desenvolvimentos da análise do discurso francesa fizeram-nos compreender a importância do papel da memória discursiva no processo de enunciação. É através de uma memória de discurso que os discursos se constituem enquanto pré-construídos ou origem de atos novos. A memória, entendida como estruturação de materialidade discursiva complexa e estendida numa dialética de repetição e de regularização, "seria aquilo que, face a um texto que surge como acontecimento a ler, vem restabelecer os "implícitos" (quer dizer, mais tecnicamente, os pré-construídos, elementos citados e relatados, discursos-transversos) de que sua leitura necessita: a condição do legível em relação ao próprio legível" (PÊCHEUX, 1990, p.52). A relação entre pré-construído e acontecimento abre a possibilidade para o novo, pois, ainda segundo Pêcheux, "sob o "mesmo" da materialidade da palavra abre-se então o jogo da metáfora, como outra possibilidade de articulação discursiva... Uma espécie de repetição vertical, em que a própria memória esburaca-se, perfura-se, antes de desdobrar-se em paráfrase (Idem, p.53). A memória, segundo Pêcheux, não é, pois, "uma esfera plana", de "conteúdo homogêneo", mas "um espaço móvel de divisões, de disjunções, de deslocamentos e de retomadas, de conflito de regularização... Um espaço de desdobramentos, réplicas, polêmicas e contra-discurso" (Idem, p.56).

LUGARES ENUNCIATIVOS: EM TEMPOS DE APARENTE HOMOGENEIDADE, A HETEROGENEIDADE SE CONFIGURA

\section{O discurso do MST}

Historicamente, o processo de exclusão social do trabalhador rural e de expropriação da terra, no país, começou com a história do descobrimento e da colonização e se manteve depois da independência. Foram dele vítimas os índios - escravizados primeiro e dizimados depois -, os escravos africanos, os mestiços, os imigrantes. As políticas brasileiras sempre favoreceram a hegemonia de pequenos grupos, que detêm o poder político e regem os destinos do país, com o conseqüente confinamento à marginalidade e à pobreza de um grande número de explorados e excluídos do direito à terra (que tinha outras funções que não a social) e sobretudo à cidadania.

No entanto, a ideologia junta as palavras às coisas, produzindo sentidos que passam como sendo a realidade, a coisa em si, uma evidência inquestionável. Para um indivíduo ser sujeito é preciso que seja afetado 
pelo simbólico, ou seja, que se submeta aos sentidos da língua, "esquecendo" que esses sentidos são decorrentes de um longo processo histórico. É necessário que acredite que esses sentidos traduzem a relação (natural e verdadeira) entre as palavras e as coisas, ou os fatos da realidade. Os sentidos dos discursos se afiguram, então, sob a forma de "universalidade", "o mundo das coisas", funcionando como se fosse a realidade ou um sistema de evidências "em si" (PÊCHEUX, 1988).

Assim é a "evidência" da preguiça natural do trabalhador rural brasileiro, a sua indolência e seu comodismo congênitos. A eficácia desses sentidos, que têm por finalidade manter um certo status quo, se dá quando os próprios desfavorecidos, explorados e excluídos se tornam sujeitos do discurso que os subjuga. Desse modo, a exclusão social do trabalhador rural é sustentada por um discurso em que são ignoradas as condições materiais de existência do lavrador brasileiro, inclusive pelo próprio lavrador. Quando esse diz, conformado com as condições materiais em que vive, "É Deus quem quis assim", "A gente vai vivendo como pode", pensando ser ele o autor de seu dizer, está aprisionado por uma memória discursiva em que esses dizeres fazem sentido, significam. Ele é sujeito do discurso de sua própria exclusão social.

A negação do direito da palavra ao agricultor está inscrita nos discursos fundadores (literário, jurídico, político, religioso etc.) e em sua memória. Essa negação chegou a ser constitutiva inclusive do discurso marxista. Em 1848, no texto do Manifesto do partido comunista, Marx e Engels (1990) chegam a afirmar que apenas o proletariado é verdadeiramente uma classe revolucionária, estando, pois, pressuposto que as demais classes não possuem consciência política, condições organizacionais, suporte ideológico, prática efetiva e instrumentos teóricos capazes de oporem-se ao poder vigente, em busca de uma sociedade igualitária.

$\mathrm{O}$ MST não surgiu, pois, aleatoriamente. $\mathrm{O}$ movimento nasceu das injustiças sociais, dentre elas a que excluiu o homem do campo do processo social e, sobretudo, do direito à palavra. O discurso do MST se insere no quadro dos discursos sobre a função social da terra. O seu sujeito é o agricultor que não fica mais mudo e nem mais repete as "evidências" que promoveram, historicamente, a exclusão social do homem do campo. Possuindo um discurso próprio, que consiste numa ruptura com o discurso do poder e das instituições, assume, agora, uma voz, enquanto agricultor, que expõe outros enunciados como novas evidências: "o Brasil tem muita terra, sim, mas ela está nas mãos de alguns poucos", "O homem da roça não é preguiçoso, ele não tem terra para plantar", por isso "Temos que fazer a reforma agrária", pois "Só a reforma agrária solucionará os proble- 
mas do campo".

Ao dizer, agora, que, como agricultor tem direito à terra, esse novo sujeito, o sem-terra, ressignifica a "universalidade dos direitos", prevista em Lei (Estatuto da Terra e Constituição). Estendendo esse direito universal ao trabalhador do campo, luta pela reforma agrária: "Como agri-

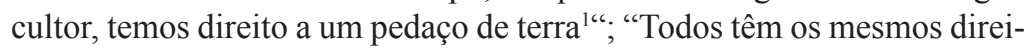
tos e tudo tem que ser dividido"; "Sem reforma agrária não há democracia". Mais do que isso, o MST se organiza enquanto movimento de massa e incentiva as ocupações: "Na luta concreta pela terra, vamos nos organizar e nos preparar para ocupação massiva". Numa etapa posterior, chama os trabalhadores da cidade para unirem-se aos agricultores, colocando-se como vanguarda dos demais movimentos populares do campo e da cidade: "Trabalhador rural e urbano, organizem-se"; "Na medida que consolidarmos uma aliança campo e cidade, vamos derrubar os muros da cidade e romper as cercas do campo". Proclama finalmente o seu projeto, que é promover a mudança da ordem social, ou seja, construir uma sociedade socialista: "Com esta aliança não só implantaremos a reforma que queremos, como também construiremos a sociedade mais justa e fraterna, a sociedade socialista"; "Construir com as demais organizações sociais, do movimento sindical, das igrejas, dos intelectuais e dos militantes em geral para a construção de um projeto para o Brasil".

Ora, a reforma agrária num país em que o latifúndio sempre representou o poder das elites é um objeto tabu. A questão da terra desnuda todo um sistema de desigualdades e privilégios, e de leis que não se cumprem. Exigir a reforma agrária é exigir que o Estado cumpra o que ele mesmo determinou em seu discurso como garantias universais a todo cidadão (o Estatuto da Terra prescreve a reforma agrária e a Constituição a confirma). Tabu do objeto, diria Foucault (1971), parte da interdição da palavra, que compreende, também, o ritual da circunstância e o direito privilegiado de quem fala. Que direitos têm os agricultores, jecas, de exigir que se cumpra o que acham que a lei determina e de propor um projeto que distribua riqueza e renda e diminua as diferenças sociais?

Sabemos que o discurso é controlado, selecionado, organizado e redistribuído a partir de determinados procedimentos que colocam em jogo seus poderes e perigos (FOUCAULT, 1971). É preciso, então, controlar os discursos e sua distribuição desde que representem qualquer ameaça à permanência do poder instituído.

${ }^{1}$ Esses enunciados do discurso do MST foram coletados e registrados por Marlon Leal Rodrigues, em sua dissertação de Mestrado: Introdução aos estudos da ideologia que sustenta o MST (Universidade Federal do Mato Grosso do Sul, 2001). 
Se não é possível ao discurso do poder calar um sem-terra, é possível controlar seus dizeres e a distribuição de seu discurso, através de outros processos de interdição. Estamos nos referindo à interdição através do controle dos sentidos. Como diz Orlandi (1999ª p. 66), os discursos do MST, "que são uma ruptura no discurso político neo-liberal, têm dificuldade de significar-se nessa margem em que muitos sentidos não podem fazer o sentido do político, onde as palavras como "movimento" podem significar algo sujeito à repressão porque resvala para o que, hoje, se considera como ilegal".

Os sem-terra são significados, pois, como um grupo de "baderneiros", "transgressores da lei", "aqueles que se tocam". Sabemos que os sentidos não existem de per si, na língua, mas são constituídos, historicamente, no interior das formações discursivas. Nos processos parafrásticos, os dizeres se mantêm, repetindo-se, enquanto procedimento de memória. Pode acontecer que, ao se repetirem, acabem por modificarem-se ou deslocarem-se, pelos processos de polissemia. Se na paráfrase temos estabilização, na polissemia temos rupturas de processos de significação. Na polissemia, temos criatividade (ORLANDI, 1999b, p. 37), pois houve a intervenção do diferente, "produzindo movimentos que afetam os sujeitos e os sentidos na sua relação com a história e com a língua" (Idem).

\section{O discurso do Fórum Social Mundial e o discurso do MST}

Conforme dissemos, os sentidos de um discurso somente se tornam viáveis pela história, pela formação de uma memória enquanto condição do legível. Questionamos, então, com relação a qualquer discurso que represente uma ruptura no discurso neoliberal, de que "implícitos", ou préconstruídos, sua leitura necessita, para que palavras como "movimento" signifiquem algo diferente de "baderna" ou "ilegalidade".

Na reportagem "A esquerda com raiva", da revista Veja, de 03 de junho de $1998^{2}$, o movimento do MST, segundo as possibilidades de leitura oferecidas por uma memória de discurso constituída a partir da ditadura militar no Brasil, conforme dissemos acima, foi classificado como "baderna" e os sem-terra como um "bando de baderneiros","transgressores da lei". O seu discurso foi chamado de "um caldeirão ideológico", discurso "desfocado", "anacrônico". Caldeirão ideológico, porque em seu discurso socialista há um pouco de tudo: Marx, Lênin, Guevara, Mao e tantos outros. Anacrônico, porque os discursos reivindicatórios de classe estão fora

${ }^{2} \mathrm{~A}$ mesma revista, no entanto, publicou outras reportagens sobre o MST não tão destrutivas, mas todas sempre de acordo com o momento político e os interesses do governo. 
de moda - não são próprios do momento atual. Desfocado, porque os discursos de esquerda não cabem mais nesse contexto de avanço do neoliberalismo econômico, marcado pela decadência dos sindicatos, pelo "fim das ideologias" e pelo "fim da história". Além do mais, segundo a revista, não existe mais uma ideologia capaz de unificar as diversas minorias socialmente marginalizadas.

No entanto, a despeito desses sentidos atribuídos pelo discurso mais conservador aos movimentos de massa, e a despeito da aparente hegemonia do discurso neoliberal global, a história tem viabilizado outras possibilidades de leitura, através da construção de um espaço de memória, que não é homogêneo. Essa heterogeneidade se deve sobretudo à inscrição de certos questionamentos ao neoliberalismo e à globalização, tais como as manifestações de protesto ocorridas em Seattle, em 1999, por ocasião da Organização Mundial do Comércio, ou as ocorridas em Washington contra o Fundo Monetário Internacional e o Banco Mundial, em 2000, ou ainda as ocorridas em Gênova, por ocasião do G-8, em 2001 e muitas outras. A possibilidade de se fazer uma leitura "não liberal" de certos documentos, alguns mais recentes, como a Carta de Princípios do Fórum Social Mundial, de julho de 2001, outros menos, como a Declaração Universal dos Direitos Lingüísticos, de 1996 (ambos se apoiando em documentos anteriores, tais como a Declaração Universal dos Direitos Humanos, de 1948), assim como os textos revolucionários que constituem o discurso do MST no Brasil e tantos outros de protesto à hegemonia neoliberal, nos leva ao reconhecimento de uma memória de discurso enquanto esse "espaço móvel de divisões, de disjunções, de deslocamentos e de retomadas, de conflito de regularização", de que nos diz Pêcheux, ou enquanto "um espaço de desdobramentos, réplicas, polêmicas e contra-discurso".

Nesse processo, o discurso do Fórum Social Mundial, cujos enunciados se encontram no registro de suas conferências (as de 2001 e as de 2002), que buscaram resgatar as alternativas que têm sido formuladas nos últimos anos pelos descontentes com a globalização, e, resumidamente, na sua Carta de Princípios, surgiu enquanto proposta de aglutinar a multiplicidade e diversidade de vozes dos que resistem à lógica do mercado, da especulação e da desigualdade social, e sobretudo para registrar "as alternativas propostas para resolver os problemas de exclusão e desigualdade social que o processo de globalização capitalista, com suas dimensões racistas, sexistas e destruidoras do meio ambiente, está criando, internacionalmente e no interior dos países"3.

${ }^{3}$ Princípio $\mathrm{n}^{\circ} 12$. 
Tratando-se de um discurso de "globalização solidária" à diversidade de gênero, etnias, línguas, culturas, gerações e capacidades físicas, pode ser considerado ainda como um discurso aglutinador dos discursos da resistência (entidades, movimentos), desde que esses não sejam discursos de representações partidárias ou de organizações militares. O discurso de "globalização solidária" do FSM acabou por dar legitimidade a outros, como o do MST, por exemplo, muito embora o movimento revolucionário do MST tenha sido um dos motivos que levaram a criação do Fórum Social Mundial ser no Brasil.

A idéia da realização do Fórum nasceu, na verdade, da necessidade que alguns intelectuais viram de se criar um "contra-Davos", em alguma parte do mundo, como resposta a Davos, ou o Fórum Econômico Mundial, realizado em Genebra, em 2000. Decidiu-se que deveria ser no Brasil, porque, segundo os idealizadores do projeto, o Brasil tem movimentos sociais importantes, sobretudo o MST, conhecido na Europa como o único movimento revolucionário no mundo 4 . Não há dúvidas de que o MST, mais do que qualquer outro movimento, pelas questões que coloca, intriga tanto os economistas a serviço do capital, que tão apressadamente se propuseram a propagar o "fim da História", a partir da declaração de Francis Fukuyama, como os ex-militantes da "esquerda", que capitularam diante da mesma declaração, como também intriga aqueles que procuram uma nova alternativa ao atual modelo. A história acabou mesmo? Se acabou, está-se começando uma outra? Mas esse "velho" discurso da "invasão" de terras não pertence a um passado que já não existe (deveria existir) mais? Assim, a mesma imprensa "oficial" que noticiou, em 19985, o quanto há de anacrônico e de desfocado em movimentos populares como o MST, numa época em que o neoliberalismo parece reinar soberano, teve de noticiar, também, poucos anos depois, "a baderna" do Primeiro Fórum Social Mundial, decidido com chope, "caipirinha" e vinho tinto, no Brasil, em Porto Alegre, constituído enquanto uma reunião de movimentos sindicais, ONGs, entidades religiosas e lideranças mundiais. As conferências do Fórum, que tiveram por objetivo buscar propostas alternativas às políticas neoliberais colocadas pelo Consenso de Washington através do Banco Mundial e do FMI, pretenderam demonstrar que o discurso da "globalização" é enganador, na medida em que oculta os interesses dos países mais ricos. Tiveram ainda o objetivo de divulgar as bases de um projeto de sociedade sem centralidade no lucro e no mercado, e fazer eco-

${ }^{4}$ Declaração de Jean Ziegler, representante da Relatoria Especial para o Direito à Alimentação, da ONU, para a revista Caros Amigos (nº 62, maio de 2002).

${ }^{5}$ Referimo-nos à mesma reportagem da revista Veja, de 03 de junho de 1998. 
ar críticas e alternativas ao neoliberalismo, favorecido pela queda do Muro de Berlim e pela hegemonia dos EUA.

Do ponto de vista da discursividade, as conferências nos chamam a atenção para um locus de ressignificação de muitos termos e enunciados correntes nos discursos da política, da economia e da mídia, ou a constituição de um processo discursivo (PÊCHEUX, 1988), conforme os exemplos a seguir. "Globalização" significa, nesse novo lugar, "exclusão", porque apenas os "países rentáveis", ou as regiões que oferecem lucro imediato entrarão no processo; ou então "arquipelaguização", ou seja, a formação de arquipélagos para a indústria - onde existe "matéria-prima" interessante para o lucro imediato, os grandes grupos econômicos se instalam; passa a significar também "miséria global", porque as populações dos "países não rentáveis" ficarão à mercê da própria sorte, sem serviços, sem escola, muitas vezes vítimas das forças armadas nacionais, constituídas de bandos rivais. "Neoliberalismo" significa "fazer funcionar livremente a maximização dos lucros e a lei dos gastos comparativos de produção", o que equivale a dizer que o capital deve poder ir a qualquer parte do mundo, ter livre circulação total, para que os lucros alcem vôo e cheguem muito alto, independentemente do destino dos povos, das regiões, dos países, das sociedades, dos Estados onde funciona a normatividade internacional. "Reforma do Estado" é o mesmo que "desmonte de projetos nacionais e de Estados do Bem-Estar Social, com a privatização de empresas produtivas estatais, de segmentos do sistema de ensino, saúde e previdência, com a abertura dos mercados, com a transformação dos aparelhos de Estado em aparelhos administrativos dos blocos mundiais de poder ou das elites transnacionais e a conseqüente dissociação entre o Estado e a sociedade civil”.

Desse modo, segundo a análise que propomos, o discurso do MST, tanto quanto o discurso do Fórum Social Mundial, filia-se a um espaço mais amplo, que podemos chamar de "espaço enunciativo de resistência ao neoliberalismo global", embora o discurso do Fórum se proponha como "discurso aglutinador" de todos os outros, com uma espécie de "síntese" do que vinha acontecendo de forma mais ou menos aleatória. Assim, se considerarmos os acontecimentos discursivos dos movimentos reivindicatórios (das minorias étnicas, culturais, lingüísticas, de classe etc.) espalhados em diferentes partes do mundo, aparentemente de forma aleatória, mas passíveis de serem aglutinados, segundo a proposta do discurso do FMS, podemos divisar, de uma forma mais explícita, um processo de produção de sentidos nos inúmeros acontecimentos colocados na mudança da estrutura social. Alguns desses acontecimentos, por suas inúmeras reto- 
madas em forma de paráfrases, ou réplicas, assim como pelas polêmicas e contra-discursos que provocam, chegam a se inscrever na memória, como nos parece ser o caso do discurso do MST.

Com relação a esses discursos, seria possível afirmar que estamos na eminência do advento de um "novo marxismo", ou de um "marxismo global", para o qual o que prevalece é o social e a dignidade humana?

Parece-nos que a emergência de um novo discurso global de resistência ao neoliberalismo se faz possível pela própria inscrição histórica do marxismo, que inaugurou, no passado, os movimentos revolucionários contra o liberalismo econômico. Todavia seria necessário investigar, mais criteriosamente, as filiações sócio-históricas desses discursos da resistência, que estamos chamando aqui de "discursos de globalização solidária", os quais nascem de uma heterogeneidade aparentemente caótica, em diferentes lugares ao mesmo tempo, e, aparentemente, sem uma ideologia definida, capaz de unificar as diversas vozes das minorias socialmente marginalizadas.

O Projeto de Lei $n^{\circ} 1676$ de 1999, do deputado Aldo Rebelo (do PC do $B, S P)$ e a "Declaração Universal dos Direitos Lingüísticos"

Nas trilhas desses novos discursos que vêm constituindo-se como o outro do discurso da globalização, propomo-nos a comparar os lugares enunciativos responsáveis pela organização de dois textos de política lingüística. O primeiro é o documento do Projeto de Lei no 1676 de 1999, do deputado Aldo Rebelo do PC do B, SP. O segundo é o documento da Declaração Universal dos Direitos Lingüísticos ("Universal Declaration of Linguistic Rights"), de junho de 1996, cunhado em Barcelona, Espanha.

A Declaração Universal dos Direitos Lingüísticos, baseando-se no documento da Declaração Universal dos Direitos Humanos, de 1948 (que defende direitos iguais a todos os seres humanos, independentemente da raça, da cor, do sexo, da língua, da religião, da posição política, da origem social ou nacional, do status de propriedade ou nascimento), procura criar uma estrutura política universal para a diversidade lingüística, baseada no respeito, na coexistência harmônica e no benefício mútuo e reivindica, para cada comunidade lingüística, o direito à sua própria língua na administração pública, no ensino, no trabalho, nas relações econômicas e comerciais, nos tribunais da Justiça, na mídia etc.

O deputado federal Aldo Rebelo apresentou ao Congresso Nacional do Brasil, em 1999, um projeto de lei que teve como objetivo a "promoção, a proteção, a defesa e o uso da língua portuguesa", propondo o uso 
obrigatório da língua "no trabalho, nas relações jurídicas, na expressão oral, escrita, audiovisual e eletrônica de todos os documentos e eventos públicos", nos meios de comunicação, na publicidade, nas embalagens "e toda e qualquer comunicação dentro do território nacional", reivindicando, pois, para "o povo brasileiro" exatamente o mesmo que a Declaração Universal dos Direitos Lingüísticos reivindica para cada comunidade lingüística. O projeto de lei do deputado pretende proteger a língua portuguesa do uso de termos estrangeiros, nessa época de globalização - prevendo até multas ${ }^{6}$ para os infratores. "Mais do que um projeto de lei", pretende criar um Movimento Nacional de Defesa da Língua Portuguesa. O projeto já passou pela Câmara dos Deputados e aguarda apenas a votação no Senado.

Todavia, segundo a análise que propomos, esses textos, dois acontecimentos no discurso de política lingüística, ambos contra a homogeneização lingüística imposta pelo colonialismo, contra a globalização e propondo coisas muito semelhantes, caminham, na verdade, em direções opostas, se considerarmos as filiações de memória que lhes sustentam os sentidos, a posição de sujeito de seus autores, assim como os deslocamentos que esses dois acontecimentos tenham inaugurado (réplicas ou contra-discursos, paráfrases etc.).

Vamos nos deter aqui às filiações de memória, mais especificamente aos diferentes sentidos que alguns vocábulos adquirem em um e em outro espaço enunciativo, tais como "comunidade lingüística", "identidade" e "língua". Escolhemos esses vocábulos porque acreditamos que temos que levar a sério que o indivíduo não tem uma identidade fixa anterior e fora da língua e que as identidades da língua e do indivíduo têm implicações mútuas, isto é, que o indivíduo se constitui enquanto sujeito pela linguagem e pela língua.

No processo discursivo que sustenta os sentidos do texto da Declaração Universal dos Direitos Lingüísticos, a oposição entre os termos "língua minoritária" e "língua oficial", ou entre "língua regional e língua oficial" não fazem o menor sentido. Todas as comunidades lingüísticas são consideradas iguais, independentemente do status "oficial" ou não de suas línguas. Uma comunidade lingüística é considerada enquanto qualquer sociedade humana estabelecida historicamente num espaço geográfico particular (seja esse espaço reconhecido ou não), desde que se identifique como um povo e tenha desenvolvido uma língua comum como um meio de

${ }^{6}$ No projeto, Aldo Rebelo propôs uma ação civil e penal contro os infratores. A Comissão de constituição de Justica alterou a "penalidade" para apneas uma sanção administrativa ou uma advertência. 
comunicação e coesão cultural entre seus membros. Nesse sentido, o termo cultura, no singular, torna-se de pouca utilidade: distintos grupos humanos, marcados por histórias singulares, tecem com suas língua(gens) distintos sistemas de referências, distintas leituras sobre o mundo, estabelecem regras de convívio, valores, produzem narrativas sobre si e o grupo, que permitem que se estabeleça entre eles um certo sentimento de pertencimento ou de identidade. Não se julga aí que a aplicação do prefixo "sub" para caracterizar essas produções (denominando-as sub-culturas) seja, igualmente, pertinente: seria necessário supor uma cultura acima de todas as outras, uma cultura padrão. E a cultura do outro seria sempre a subcultura.

Não é difícil reconhecer aí uma relação de aliança com o discurso da Lingüística moderna, sobretudo com o da Sociolingüística, que desenvolveu, a partir de estudos sobre a questão da diversidade lingüística, a tese de que todas as comunidades lingüísticas devem ser consideradas de igual valor, independentemente do status "oficial" de suas línguas ou dialetos ou do número de seus falantes.

Em contrapartida, no texto do deputado, "língua" é apenas aquela considerada a "oficial". "Povo brasileiro" e "comunidade lingüística" são termos sinônimos, o que implica que no Brasil existe uma só comunidade lingüística. É por isso que enuncia, na justificação do documento, "um autêntico milagre brasileiro", que é o de existir apenas uma língua no Brasil para todo o povo brasileiro:

"um dos elementos mais marcantes da nossa identidade nacional reside justamente no fato de termos um imenso território com uma só língua, esta plenamente compreensível por todos os brasileiros de qualquer rincão, independentemente do nível de instrução e das peculiaridades regionais da fala e da escrita" (REBELO, 1998).

De fato, temos apenas uma "língua oficial" no Brasil, mas, se formos considerar o que não é oficial, o Brasil não é um país monolíngüe. Hoje são faladas no Brasil, por cidadãos brasileiros natos, cerca de 203 línguas (MAHER, 1997, p. 22). São 170 línguas indígenas, 30 línguas de imigrantes, 2 línguas de sinais e evidentemente a língua portuguesa, o que revela uma heterogeneidade lingüística, cultural e social muito grande.

Vale, então, aqui perguntar por que não se inscreveu na mémoria desse discurso nacionalista, de que o deputado se faz sujeito, o fato de que, nos 500 anos de nossa história, nunca fomos monolíngües. Por que ficou nessa memória o "fato" de que somos um país monolíngüe em língua portuguesa e apagou-se a existência de populações e grupos falantes de outras 
línguas, tais como os indígenas, os imigrantes, os habitantes de regiões fronteiriças (casos de bilingüismo), os surdos etc. A questão que então colocamos é: porque este perverso esquecimento se produz?

Perguntamos ainda por que se produziu o esquecimento de que até o século XIX, no país, a cada três brasileiros, apenas um falava português, já que os demais falavam a língua geral. Outro "esquecimento" é que o Português foi decretado como única língua do estado brasileiro apenas em 1988, ou seja, apenas há quatorze anos. Em 1988 aparece, pela primeira vez na Constituição, que a língua oficial do Estado Brasileiro é a Língua Portuguesa. Nesse ano, o Estado Brasileiro determinou, implicitamente, que o português deveria ser a língua de instrução nas escolas públicas, embora, vale lembrar, ações insistentes para a priorização do ensino em língua portuguesa já estivessem presentes no período pombalino (VIEIRA DA SILVA, 1998). E porque essas ações se mantiveram cada vez mais tenazes não causou grande impacto social a determinação constitucional de 1988.

No texto da Declaração Universal dos Direitos Lingüísticos, reconhece-se o direito que toda pessoa tem de ser educada (em todos os níveis, inclusive o superior) na língua de sua comunidade lingüística, o que não lhe exclui o seu direito de adquirir conhecimento de qualquer outra língua que deve ser usada como instrumento de comunicação com outras comunidades lingüísticas. A educação deve ajudar a manter e a desenvolver a língua falada pela comunidade, assim como sua cultura. No texto do deputado, reforça-se o que reza a Constituição Brasileira quanto à obrigatoriedade, no ensino e na aprendizagem, do "uso da língua portuguesa por brasileiros natos e naturalizados e pelos estrangeiros residentes no país há mais de 1(um) ano", não se fazendo nenhuma referência ao direito que os brasileiros natos, como os índios, praticantes de outras línguas que não o português, têm de serem educados na língua de sua comunidade. Aos membros das comunidades indígenas nacionais não se impõe a obrigatoriedade (porque certamente não são considerados coisa alguma, nem brasileiros e nem estrangeiros), como também não se mencionam os seus direitos ${ }^{7}$.

Vieira da Silva (1998), a partir da análise de textos e documentos de diferentes épocas (discursos religiosos dos séculos XVI e XVII e outros considerados científicos, produzidos entre os séculos XIX e XX), mostra como certas filiações entre o discurso religioso e o discurso científico produziram, como efeito, não apenas saberes sobre o sujeito-aluno fundados

${ }_{7}^{7}$ Tratamos mais especificamente a questão do ensino em outro trabalho (SOUZA; CARDOSO, 20010. 
em oposições - ser letrado/civilizado e não letrado/não civilizado/não cidadão - como também a construção histórica/ideológica da ilusão de sermos um país monolíngüe. Articulados historicamente às políticas públicas de educação, tais saberes têm gerado o aniquilamento de nossas "minorias" étnicas e culturais e mantido a crença geral de que todas as milhões de pessoas que vivem no Brasil são monolíngües em Português.

Outro "esquecimento" no discurso do deputado é quanto à heterogeneidade da língua portuguesa. Tal esquecimento (re)produz a crença de que a língua portuguesa é uma totalidade homogênea, ou que as diferenças, quando existem, são superficiais, revelando-se o mais das vezes na pronúncia de certas palavras e no vocabulário e só na língua oral.

Ora, o português (e isso a Lingüística não tem cansado de demonstrar!) é um conjunto de variedades, de dialetos sociais e dialetos regionais, que não podem ser considerados "variedades mínimas". Aquilo que chamamos de "a língua portuguesa", "a nossa língua portuguesa", pensando ser uma unidade, uma força unificadora, acima de qualquer diferença cultural, regional, é de fato constituída de uma enorme variedade que abrange aspectos de pronúncia, de vocabulário, de sintaxe, e, principalmente, de modos de organizar e representar a realidade, modos de constituir diferentes identidades.

É um equívoco tomar essas variedades por "desvios", "desvios mínimos", "o que não impede que as pessoas se entendam entre si”. Não é verdade, como quer o deputado, que temos uma língua única "plenamente compreensível por todos os brasileiros de qualquer rincão, independentemente do nível de instrução e das peculiaridades regionais da fala e da escrita", porque os brasileiros falantes dos dialetos de baixo prestígio do português nem sempre têm acesso aos dialetos das elites, principalmente àquele que se impôs como "oficial".

Deste modo, em nome de uma proposta "nacionalista", não se leva a sério o tripé língua/indivíduo/identidade, no que acarreta o aniquilamento de línguas, dialetos, culturas, identidades nacionais e, com elas, grupos étnicos, grupos sociais, brasileiros que não pertencem às elites e que não conhecem a "língua nacional" (tais como as nossas populações indígenas, os brasileiros filhos de imigrantes que aqui vivem, as nossas populações menos privilegiadas economicamente, a nossa população surda-muda).

Não é difícil reconhecer aí, sustentando os sentidos dessa proposta nacionalista, o discurso da Gramática Normativa, para a qual a língua portuguesa é considerada enquanto uma identidade supra-cultural, supraregional, supra-dialetal, acima, portanto, dos dialetos que não são das elites, acima das identidades nacionais brasileiras que não são as elites. $\mathrm{E}$ 
seria importante questionar por que, numa época de hegemonia do neoliberalismo global, os gramáticos estão em alta. Basta que liguemos as nossas televisões, e vamos ver o quanto as emissoras têm prestigiado, por meio das lições de certos gramáticos, a antiga oposição entre "falar certo" e "falar errado". Com a ajuda desses gramáticos, não só as emissoras de $\mathrm{TV}$, como também nossos mais prestigiados jornais e revistas ainda cultivam o mito de uma língua pura, estável, correta, homogênea, a despeito de todo o trabalho científico empreendido, em muitas décadas e em diferentes países, sobre a questão da realidade lingüística e sobre as questões ideológicas relacionadas à heterogeneidade lingüística.

O texto do deputado revela tal filiação, nas inúmeras referências, enaltecedoras quase sempre, que faz aos gramáticos conservadores (muitas vezes elevados ao estatuto de "nossos maiores lingüistas", como Napoleão Mendes de Almeida), aos programas de rádio e TV sobre a língua portuguesa, aos artigos em revistas, aos manuais de redação dos principais jornais do país, "especialmente sobre seu uso no padrão culto", à variedade de livros sobre o assunto, "particularmente a respeito de como evitar erros e dúvidas no português contemporâneo", à Academia Brasileira de Letras, à qual, segundo o deputado, cabe o parecer de atualização das normas do Formulário Ortográfico do Português etc.

Assim, no texto do deputado, "língua" quer dizer "língua oficial", "padrão", "escrita", "da elite", e sobretudo "correta". Não raro, no texto, confunde-se "língua" com a própria "gramática" (normativa), em passagens como: "apesar de certas regras tortuosas, o português é belo".

Ora, não é o português que tem regras tortuosas; é a gramática normativa que as tem. A língua não é a gramática ${ }^{8}$, pelo menos não a normativa. Essa é um saber, um discurso sobre a língua-padrão, ou melhor, sobre aquilo que se imagina que deva ser o padrão escrito da língua. No entanto, aquilo que as nossas gramáticas normativas preconizam como o que deve ser a língua escrita padrão não existe, não está em lugar nenhum: não está na produção literária, nem na produção científica, nem na imprensa escrita. O que a gramática pensa ser a língua portuguesa padrão é um ideal abstrato de uma classe detentora do poder. Isso é muito contraditório porque nem mesmo a classe detentora do poder conhece essa língua idealizada, porque também as elites, quando falam, praticam seus próprios dialetos, e, quando escrevem, se demonstram um bom domínio da escrita, acabam por se esquivar de muitas daquelas regras gramaticais que não

${ }^{8}$ Devemos insistir na distinção entre língua padrão e gramática normativa. Quando atacamos certos aspectos da gramática normativa (e são muios os aspectos que merecem ser criticados), não estamos atacando o padrão culto da língua portuguesa, de que nos beneficiamos inclusive para escrever este artigo. 
cabem mais no contexto atual, tais como colocações lusitanas de pronomes átonos, regências verbais e nominais que o uso jamais consagrou, concordâncias que não se sustentam etc.

Dissemos mais acima que o texto do deputado, apesar de uma aparente semelhança com o texto da Declaração Universal dos Direitos Lingüísticos, pertence a uma outra formação discursiva. Seguindo essas filiações de memória, é possível afirmar que o discurso nacionalista e o discurso da globalização neoliberal partilham sentidos, sobretudo se considerarmos os significados que adquire, no interior desses discursos, o enunciado "levar civilização aonde essa não existe". Levar aos "não civilizados" uma cultura, uma religião ou uma língua, pode ser tomado um "bem" ou um "dever cristão", como aquele defendido durante a expansão colonialista de Portugal e Espanha, ou ainda uma "face humana" do capitalismo, como defendia J.Kenyes, nos anos 40. Assim, preocupado com a dominação estrangeira que estaria se impondo sobre a língua portuguesa hoje, ou seja, preocupado com os processos da globalização através das formas de dominação de um povo sobre o outro pela imposição da língua (na verdade, com o "colonialismo norte-americano"), o texto do deputado se "esquece" do processo histórico (e ainda em pleno desenvolvimento nos dias de hoje) de dominação ou colonialismo, no Brasil, pela imposição do português, dito "padrão", "oficial", sobre os povos indígenas, praticantes de outras línguas, sobre as populações mestiças, sobre uma imensa população praticante de dialetos de menor prestígio do português etc.

Um maior aprofundamento na questão nos levaria à relação entre neoliberalismo, enquanto teoria, prática e discurso do globalismo, e liberalismo, enquanto teoria, prática e discurso do nacionalismo, o que nos permitiria afirmar que o globalismo é um nacionalismo de tipo "global".

\section{CONSIDERAÇÕES FINAIS}

De acordo com um aconselhamento do velho Marx de que o revolucionário deve ser capaz de entender o crescimento da planta e prestar muita atenção ao novo que surge, procuramos, por meio de acontecimentos discursivos aparentemente não muito significativos ou ameaçadores do neoliberalismo global, postular a existência de um novo espaço de memória, como condição do legível dos enunciados dos discursos que aqui batizamos como "discursos de resistência" ou "discursos de globalização solidária", os quais, constituindo-se independentemente dos partidos políticos e sem uma ideologia aparentemente definida, podem corresponder a uma nova forma de poder, capaz de ameaçar a hegemonia neoliberal a médio 
ou a longo prazo.

Esse novo espaço novo, que estamos postulando para os discursos revolucionários de tipo novo (não políticos, não partidários), não necessariamente dependentes da luta de classe (não necessariamente marxistas, portanto), também podem ser considerados como pertences ao espaço da "globalização", mas enquanto um espaço para a inscrição na memória dos discursos de efeito social colateral que o sistema liberal globalizado engendra. Para escutar suas vozes, basta ouvir os amplos setores da sociedade civil, nacional e mundial, segundo as reivindicações dos setores sociais, grupos e classes subalternos, em todo o mundo.

Ao trazermos aqui o texto do deputado Aldo Rebelo e apontarmos o quanto esse se encontra longe de pertencer a um novo discurso, ou a uma proposta anti-neoliberal, nossa intenção foi mostrar que aquilo que se apresenta como algo novo pode ser "o mesmo", pincelado de tintas novas. Não quisemos passar a idéia de que somos contrários a uma política lingüística ou que somos favoráveis à entrada, sem qualquer escrutínio, de estrangeirismos no português. Por isso, para encerrarmos nosso trabalho, um esclarecimento deve ser feito: achamos que nós, lingüistas, devemos, sim, continuar defendendo que as línguas são entidades dinâmicas, históricas, heterogêneas, sujeitas a empréstimos, mas também devemos defender que o Brasil deva ter uma política lingüística, justamente porque, ao afirmarmos que as línguas são entidades históricas, não podemos separar língua, nação e identidade. Se a língua se vincula a identidade e a nação, ela já não pode caminhar independentemente, sozinha, como uma coisa "natural”, sujeita às suas próprias leis e à própria sorte. Justifica-se, assim, que uma nação deva ter o seu planejamento lingüístico.

Ainda que o texto do deputado não fale de um lugar novo, pelas razões aqui expostas - principalmente pelo fato de repetir as velhas "verdades" naturalizadas pelo discurso dos colonizadores do passado e do presente -, temos de reconhecer que desencadeou uma enxurrada de novas enunciações, na verdade, toda uma polêmica, que nos fez reconhecer o quanto estamos necessitados de um projeto (não equivocado!) de política lingüística, que não vise apenas à defesa do português contra o abuso dos estrangeirismos, mas que, principalmente, contemple a realidade do país, assegurando os interesses e necessidades das populações que aqui vivem e que formam, de uma maneira um tanto peculiar, pela sua heterogeneidade étnica, cultural e lingüística características, o "brasileiro". Um projeto novo, que seja capaz, ao mesmo tempo, de lidar apropriadamente com a heterogeneidade étnica, lingüística e cultural do Brasil, de modo a considerar as diferenças como possibilidades a serem partilhadas (sem cair num 
ideal homogeneizador de língua, de sujeito e de cultura), e de assegurar a todos os brasileiros, de qualquer rincão ou classe social, a possibilidade de domínio pleno das variedades mais cultas do português e de possibilidade de acesso aos bens culturais das elites.

Mais um discurso que se agrega aos tantos outros que se constituem "à margem" do discurso neoliberal? Que seja bem-vindo!

\section{BIBLIOGRAFIA}

FOUCAULT, M. L'ordre du discours. Paris, Gallimard, 1971.

FORUM SOCIAL MUNDIAL. Carta de Princípios. Revista Caros Amigos, $\mathrm{n}^{\mathrm{0}}$ 57, dezembro de 2001,

GUILHAUMOU, J.; MALDIDIER, D. Da enunciação ao acontecimento discursivo em análise do discurso.IN: GUIMARÃES, E. (org.). História e sentido na linguagem. Traduzido por Freda Indursky. Campinas, Pontes, 1989.

MAHER, T. M. O dizer do sujeito bilíngüe: aportes da sociolingüística. Anais do Seminário Desafios e Possibilidades na educação Bilíngüe para Surdos. Rio de Janeiro, Instituto Nacional de Educação de Surdos, 1997, p. 20-26

MARX K. E ENGELS, F. Manifesto do partido comunista. $3^{\mathrm{a}}$ ed. Petrópolis. Vozes. 1990. (Tradução do original de 1848).

PÊCHEUX, M. Semântica e discurso: uma crítica à afirmação do óbvio. Traduzido por Eni Pulcinelli Orlandi et alii. Campinas, UNICAMP, 1988.

. Discurso: estrutura ou acontecimento. Traduzido por Eni Pulcinelli Orlandi. Campinas. Pontes. 1990.

ORLANDI, E.P. Maio de 1968. Os silêncios da memória. IN: ARCHARD, P. et alii. Papel da memória. Campinas, Pontes, 1999a.

_. Análise do discurso: princípios e procedimentos. Campinas, Pontes, 1999b.

REBELO, A. Projeto de Lei n ${ }^{\circ}$ 1676, de 1999, Congresso Nacional.

RODRIGUES, M.L. Os discursos do MST. Dissertação de Mestrado, UFMS, 2001.

SOUZA, R. M.; CARDOSO, S.H.B. Inclusão escolar e linguagem revisitando os PCNs. Proposições, Campinas, UNICAMP/ Faculdade de Educação, vol. 12, n. 2-3 (35-36), jul-nov 2001, p.32-45.

32 
VIEIRA DA SILVA, M. História da alfabetização no Brasil - a constituição de sentidos e do sujeito da escolarização. Tese de doutorado, UNICAMP/ Instituto de Estudos da Linguagem, 1998. 